\title{
Long-Term Trend Analysis of Precipitation and Extreme Events over Kosi River Basin in India
}

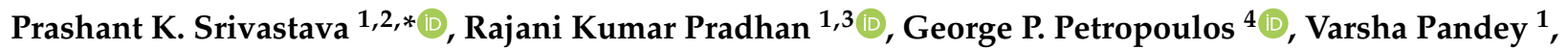 \\ Manika Gupta ${ }^{5}$, Aradhana Yaduvanshi ${ }^{6}{ }^{\circ}$, Wan Zurina Wan Jaafar ${ }^{7}$, Rajesh Kumar Mall ${ }^{2}$ () \\ and Atul Kumar Sahai ${ }^{8}$ (D)
}

1 Remote Sensing Laboratory, Institute of Environment and Sustainable Development, Banaras Hindu University, Varanasi 221005, India; rkpradhan462@gmail.com (R.K.P.); varshu.pandey07@gmail.com (V.P.)

2 DST-Mahamana Centre for Excellence in Climate Change Research, Institute of Environment and Sustainable Development, Banaras Hindu University, Varanasi 221005, India; rkmall@bhu.ac.in

3 Faculty of Environmental Sciences, Czech University of Life Sciences Prague, Kamýcká 129, 16500 Praha-Suchdol, Czech Republic

4 Department of Geography, Harokopio University of Athens, 17671 Athens, Greece; petropoulos.george@gmail.com

5 Department of Geology, University of Delhi, New Delhi 110052, India; manikagup@gmail.com

6 Department of Civil Engineering, IIT Bombay, Powai 400076, India; aradhanayaduvanshi10@gmail.com

7 Department of Civil Engineering, University of Malaya, Kuala Lumpur 50603, Malaysia; wzurina@um.edu.my

8 Indian Institute of Tropical Meteorology, Pune 411021, India; sahai@tropmet.res.in

* Correspondence: prashant.iesd@bhu.ac.in

check for updates

Citation: Srivastava, P.K.; Pradhan R.K.; Petropoulos, G.P.; Pandey, V.; Gupta, M.; Yaduvanshi, A.; Wan Jaafar, W.Z.; Mall, R.K.; Sahai, A.K. Long-Term Trend Analysis of Precipitation and Extreme Events over Kosi River Basin in India. Water 2021, 13, 1695. https://doi.org/ 10.3390/w13121695

Academic Editor: Momcilo Markus

Received: 14 May 2021

Accepted: 12 June 2021

Published: 18 June 2021

Publisher's Note: MDPI stays neutral with regard to jurisdictional claims in published maps and institutional affiliations.

Copyright: (c) 2021 by the authors. Licensee MDPI, Basel, Switzerland. This article is an open access article distributed under the terms and conditions of the Creative Commons Attribution (CC BY) license (https:/ / creativecommons.org/licenses/by/ $4.0 /)$.

\begin{abstract}
Analysis of spatial and temporal changes of long-term precipitation and extreme precipitation distribution at a local scale is very important for the prevention and mitigation of water-related disasters. In the present study, we have analyzed the long-term trend of 116 years (1901-2016) of precipitation and distribution of extreme precipitation index over the Kosi River Basin (KRB), which is one of the frequent flooding rivers of India, using the $0.25^{\circ} \times 0.25^{\circ}$ resolution gridded precipitation datasets obtained from the Indian Meteorological Department (IMD), India. The non-parametric Mann-Kendall trend test together with Sen's slope estimator was employed to determine the trend and the magnitude of the trend of the precipitation time series. The annual and monsoon seasons revealed decreasing trends with Sen's slope values of -1.88 and -0.408 , respectively. For the extreme indices viz. R10 and R20 days, a decreasing trend from the northeastern to the southwest part of the basin can be observed, whereas, in the case of highest one-day precipitation (RX1 day), no clear trend was found. The information provided through this study can be useful for policymakers and may play an important role in flood management, runoff, and understanding related to the hydrological process of the basin. This will contribute to a better understanding of the potential risk of changing rainfall patterns, especially the extreme rainfall events due to climatic variations.
\end{abstract}

Keywords: precipitation; Mann-Kendell test; Sen's estimator test; extreme events; Kosi River Basin

\section{Introduction}

Extreme weather events, such as frequent droughts and floods, have profound impacts on both economic and human welfare [1]. Recently, India has faced several extreme rainfall events that have resulted in large damage to infrastructure and affected the lives of millions of peoples. The long-term precipitation pattern and trend, especially the extreme events, are prerequisites in the regions where flood often causes major damage to the lives and crops. For this reason, communities need high-quality scientific information on the particular historic rainfall trends for their region, including rainfall extremes, to support adaption to changes in the rainfall that are both relative to current climate variability and future climatic change [2-4]. 
Rainfall is the most important form of precipitation; it is considered as one of the principal sources of water to the earth $[5,6]$. Accurately predicting precipitation trends is a great concern to the hydrologists and water resource planers from the past centuries as the economy, development, and livelihood of the nation greatly depend on the water resource availability of that region. In addition, precipitation is considered an important hydro-meteorological variable and a vital part of the hydrologic cycle; thus, small changes in its pattern directly influence the water resources of concerned regions [7,8]. Moreover, changes in the precipitation pattern of the region adversely affect agricultural productivity, food security, future irrigation projects, land use, land cover, biodiversity, and the overall climate of the region [9]. Furthermore, the intense rainfall in a short duration is the main cause for most of the floods, landslides, soil erosion, and sedimentation problems in the dams, and it has consequences on the overall water availability and water quality [10]. A possible change in precipitation would influence the runoff, soil moisture, and groundwater reserves of the region. In this context, the identification, verification, and quantification of trends in precipitation and its spatial distribution are important challenges due to significant changes in the global climate in the last 10 decades [11]. The impact of climate change on water resources is felt worldwide, but it is more prominent in the places where flooding or drought takes place; particularly in India, due to its diverse geography, the climatic condition has significant spatial and temporal variations [12-14]. Therefore, it is necessary to know the trend of historical rainfall, which forms the basis of future forecasting of discharge and hydrologic processes for preventive measures.

Several studies have been carried out in India to address the important issues of a trend of rainfall at national, local, and regional scales. For instance, Kumar, et al. [15] carried out trend analysis over India (35 sub-division) using 135 years (1871-2005) long-term precipitation data and reported that half of the subdivisions were showing an increasing trend with only Haryana, Punjab, and Karnataka showing significant trends, while only one subdivision, Chhattisgarh, out of 15 showed a decreasing trend. Similarly, Rabindra K. Panda [16] found a decreasing trend in non-monsoon and an increasing trend in monsoon seasons in the mid Mahanadi river basin. Moreover, Mirza, et al. [17] conducted a trend analysis over Ganges, Brahmaputra, and the Meghna River Basin using the precipitation time-series data from the 16 meteorological stations and revealed that precipitation in the Ganges basin is largely stable, while increasing and decreasing trends in the subdivisions of the Brahmaputra and Meghna basin were present. Furthermore, in the Sindh River Basin, Gajbhiye, Meshram, Singh, Srivastava and Islam [7] found a significant increasing trend in both seasonal and annual rainfall. Similarly, Chandrakar, et al. [18] analyzed the long-term trend precipitation (1901-2015) and reported a significant decreasing trend on Kharun watershed, Chhattisgarh, India. Very few studies have been made on precipitation extremes over Kosi River Basin (KRB) and flood assessment [19]. Shrestha et al. [20] analyzed the long-term trend of precipitation and temperature extremes over KRB from 1975 to 2010 and found an increase in extreme events and annual rainfall intensity. Nepal [21] made a projection of extreme climate over the KRB using the high-resolution Providing REgional Climates for Impacts Studies (PRECIS) and found an increase in future frequency and intensity of consecutive dry days and very wet days, and with a greater increase in the southern plains than the northern mountain regions. Agarwal, et al. [22] analyzed future precipitation and extremes over the Kosi River Basin using outputs from 10 General Circulation Models (GCMs) and found an increasing wet spell and decreasing dry spell length. Despite the few studies conducted over the whole KRB, most of them have given preference to the part of the Kosi lying in Nepal; datasets were used from the Nepal region for validation, and to the best of our knowledge, there are no studies on long-term precipitation and extremes conducted over the KRB lying in the India.

The lower alluvial part of this KRB lies in the Bihar plains of eastern India and comprises about $38 \%$ of the total drainage area having high population density. This part of the basin is more vulnerable to floods, thunderstorms, and heavy rainfall [23]. In the past 19th century, various plans for flood controls in the lower reaches were adopted by 
both Nepal and India after the amplified socio-political pressure. The first embankment was built in 1959, the Kosi Barrage was built in 1964, and until now, about $2800 \mathrm{~km}$ of embankments have been built in southern Nepal and the northern Bihar across the basin, but they have been unsuccessful in preventing the floods and extreme disasters that occur frequently. These regular causalities contribute to agricultural losses, extensive socioeconomic damage, and displacement of thousands of inhabitants across the lower KRB [24]. Therefore, the accurate spatio-temporal characteristics of precipitation patterns, trends, and its extreme distribution in changing climate are requisite to examine the climate-induced changes and endorse policymakers to implement adequate intervention strategies for water resource management, agriculture, and allied sectors for this large, densely populated, and fertile region.

In this context, the main aim of the present study is to understand the spatial and temporal distribution of long-term historical precipitation and extreme rainfall indices over the KRB, Bihar, India. As Kosi is considered responsible for the most devastating floods in India and Nepal, the long-term analysis of the trend will help the policymakers and the water managers to make future projections and take necessary precursory measures in advance. Information regarding precipitation trends may also assist with the water resource planning and management in the basin.

\section{Study Area}

This study is carried out in the lower catchment of the Kosi River Basin, which is situated in northern Bihar, India. Geographically, it lies between $85.05^{\circ} \mathrm{E}$ to $87.31^{\circ} \mathrm{E}$ and $25.32{ }^{\circ} \mathrm{N}$ to $26.88^{\circ} \mathrm{N}$ and is one of the major sub-basins of the river Ganga. The altitude of the region, which is derived from the Shuttle Radar Topography Mission (SRTM) Digital Elevation Model (DEM), ranges from $21 \mathrm{~m}$ to $98 \mathrm{~m}$ above mean sea level (Figure 1). It is also known as the "Sorrow of Bihar" for its frequent and devastating floods. After a flow path of about $58 \mathrm{~km}$ from Nepal, the Kosi River enters Bihar, India near Bhimnagar, and after covering $260 \mathrm{~km}$, this river joins the Ganga near Kursela. The major land use land cover of the basin includes croplands and barren lands. The study area gets the most rainfall from the monsoon season (June to September: JJAS), and the annual temperature varies within a year from $0^{\circ}$ to $43^{\circ} \mathrm{C}$. The mean annual rainfall is around $1200 \mathrm{~mm}$, and most of the precipitation is received in the monsoon seasons i.e., from June to September. The dominant land cover type is agricultural croplands, current fallow lands, and water bodies. The river forms an alluvial fan due to the large sediment load from the Himalayas region and has a general slope from north to south and west to east [25].

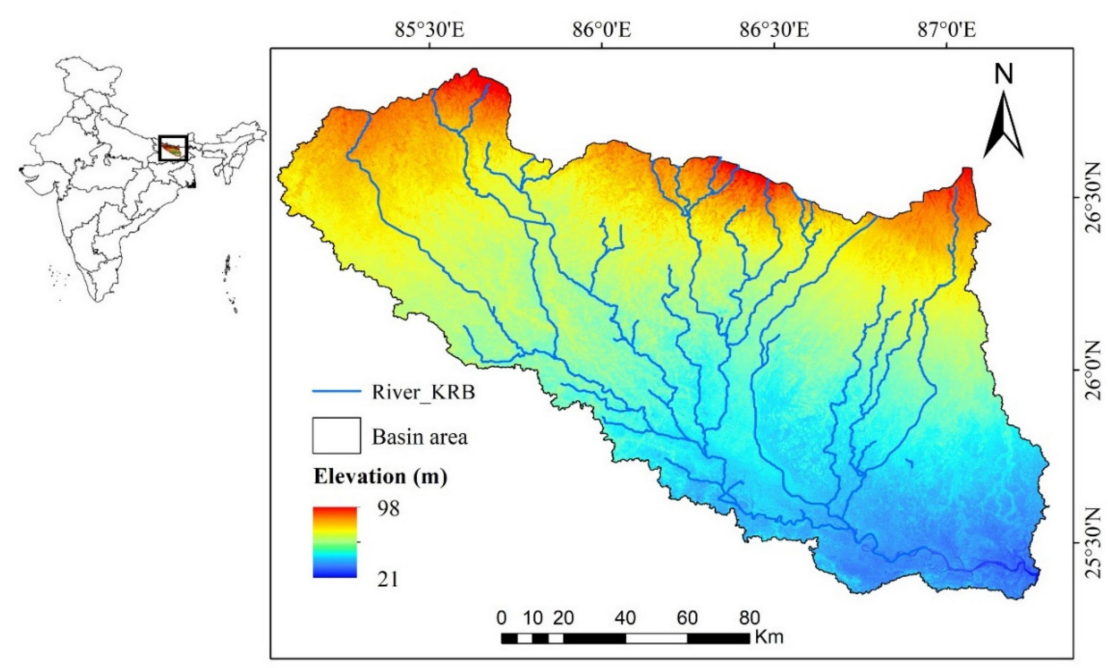

Figure 1. The geographical location of the KRB showing ground elevation (meter) using the SRTM DEM. 


\section{Materials and Methodology}

For the trend analysis, the rain gauge derived daily gridded $\left(0.25^{\circ} \times 0.25^{\circ}\right)$ precipitation data have been used for the period of 1901-2016. This precipitation product was developed by the Indian Meteorology Department (IMD) using approximately 6955 reasonably good working condition rain gauge stations across India, which was followed by quality checking, handling lots of missing data, and unexpected outliers in rainfall values. However, for daily time steps, rainfall observation is collected from about 3500 gauge stations. The Inverse Distance Weighted (IDW) interpolation technique is utilized for continuous gridded data generation [26,27]. Since IMD rain-gauge datasets utilized more observations than other precipitation datasets available at different sources, they are quite appropriate for climate change and long-term meteorological extremes-related studies. To assess the trend of the long-term precipitation, the non-parametric Mann-Kendall test and Sen's slope estimator were employed to estimate the magnitude of the trend. For the trend analysis, the daily time series data were aggregated to monthly and annual time series of the variables. As per IMD, there are four different seasons in India: namely, winter (December-February), summer (March-May), Monsoon (June-September), and post-monsoon (October-November). Furthermore, as more than $80 \%$ of the precipitation is contributed during the monsoon season, the trend analysis of only the monsoon season is considered for the seasonal trend analysis. The $\mathrm{R}$ programming language was used for the performance of the Mann-Kendall statistical test and Sen's slope estimation is used for the precipitation time series. Furthermore, with the daily gridded rainfall datasets, RClimDex software was used for the estimation of extreme precipitation indices at both grid-wise and area-weighted basin scale.

\subsection{Trend Analysis}

In the present study, the Mann-Kendall (MK), a non-parametric test, is applied to determine the monotonic trend of the given time-series data. It is a widely used test for the detection of a statistically significant trend in variables such as rainfall, temperature, and discharge [28-32]. As it is the rank-based procedure and it compares the relative magnitude of the data rather than the data values themselves, it is robust for skewed data not affected by the outliers [33]. The main advantages of using the MK test instead of others are as follows: first, it is assumption independent; i.e., there is no need for the assumption of normal distribution of the data, and second, it is not affected by the missing values. The main objective of the test is to review statistically whether there is a monotonic upward (increasing) or downward (decreasing) trend in the variable of interest over time. The MK test tests the null hypothesis, which assumes that there is no trend (the data are random and randomly ordered) against the alternative hypothesis of there being a monotonic trend present in the data over time. Sen's slope [34] is another non-parametric method used for the estimation of the magnitude of the trend in time. If the time series is showing a linear trend, the true slope could be measured by using Sen's slope method formulated by Sen [35]. It is the median of slopes of all data value pairs.

\subsection{Extreme Precipitation Indices}

The Expert Team on Climate Change Detection and Indices (ETCCDI) has recommended a list of 27 extreme precipitation and temperature indices to estimate extreme events. These indices are based on the daily temperature and precipitation amount. In recent years, many studies have analyzed these indices at both regional and global scales [36-39]. In this study, we considered 6 precipitation indices out of the 27 indices, viz. Consecutive Dry Days (CDD), Consecutive Wet Days (CWD), RX1 day (one-day highest precipitation), R10 (number of heavy precipitation days), R20 (number of very heavy precipitation days), and Simple Daily Intensity Index (SDII). These indices were computed using Climate Data Operators (CDO) software. The list of precipitation indices used, and the definition and units, are given in Table 1. Additionally, details about the extreme events 
can be found at the website http:/ / etccdi.pacificclimate.org/indices_def.shtml (accessed on 20 December 2017).

Table 1. Extreme precipitation indices.

\begin{tabular}{ccc}
\hline Indices & Definition & Units \\
\hline CDD & Maximum number of consecutive dry days with $\mathrm{RR}<1 \mathrm{~mm}$ & days \\
CWD & Maximum number of consecutive wet days with $\mathrm{RR}>1 \mathrm{~mm}$ & days \\
RX1 day & Monthly maximum 1-day precipitation & $\mathrm{mm}$ \\
R10 & Annual count of days when PRCP $\geq 10 \mathrm{~mm}$ & days \\
R20 & Annual count of days when PRCP $\geq 20 \mathrm{~mm}$ & days \\
SDII & Annual total precipitation divided by the number of wet days & $\mathrm{mm} /$ day \\
& (defined as PRCP $\geq 1.0 \mathrm{~mm}$ in the year & \\
\hline
\end{tabular}

\section{Results and Discussion}

\subsection{Evaluation of Rainfall Dataset}

The annual monthly mean and standard deviation of the 116 years of rainfall data of KRB is shown in Figure 2a. As it can be seen from the figure, the monsoon season plays an important role in the total annual precipitation. Furthermore, Table 2 represents the basic statistics such as mean, maximum, minimum, and standard deviation of the precipitation time series in the KRB. In the monsoon season, the maximum mean monthly precipitation was observed for July $(343.03 \mathrm{~mm})$ followed by August $(294.70 \mathrm{~mm})$ and September $(223.48 \mathrm{~mm})$. The minimum rainfall occurs in December (winter season). The standard deviation also follows a similar pattern: maximum for July and minimum for December.
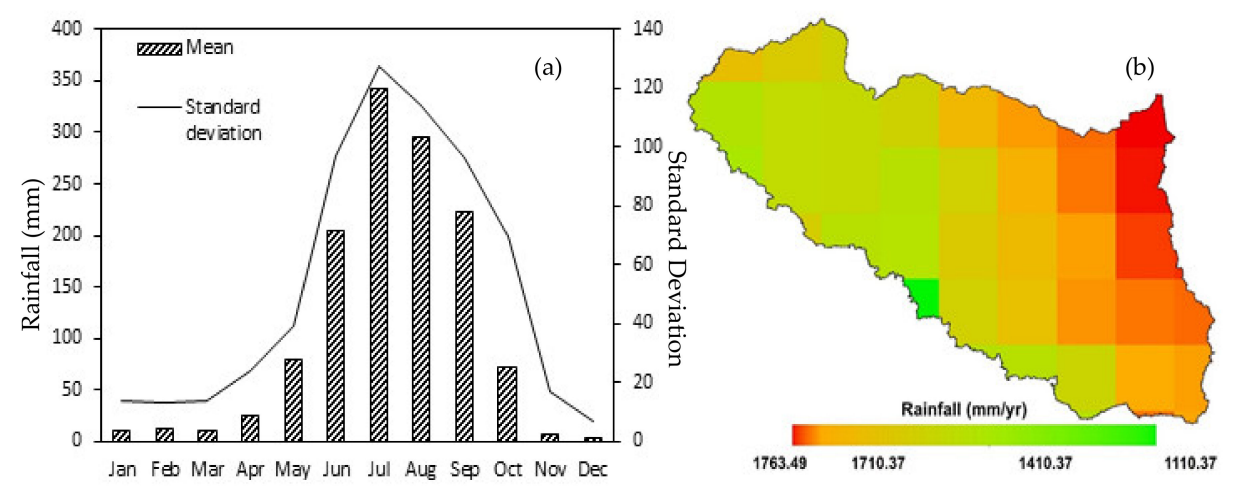

Figure 2. Characteristics of long term (1901-2016) precipitation over KRB; (a) Regionally averaged mean monthly precipitation and (b) Spatial distribution of mean annual precipitation.

Table 2. Basic statistical characteristics of the 116 years precipitation of KRB.

\begin{tabular}{ccccc}
\hline Month & $\begin{array}{c}\text { Max } \\
(\mathbf{m m})\end{array}$ & $\begin{array}{c}\text { Min } \\
(\mathbf{m m})\end{array}$ & $\begin{array}{c}\text { Mean } \\
\mathbf{( m m )}\end{array}$ & $\begin{array}{c}\text { Standard } \\
\text { Deviation }\end{array}$ \\
\hline Jan. & 80.31 & 0.00 & 10.73 & 13.85 \\
Feb. & 58.80 & 0.00 & 11.72 & 13.17 \\
Mar. & 67.74 & 0.00 & 10.97 & 13.91 \\
Apr. & 122.37 & 0.00 & 25.40 & 23.84 \\
May. & 186.54 & 2.62 & 78.80 & 39.57 \\
Jun. & 545.82 & 44.10 & 205.12 & 97.28 \\
Jul. & 715.12 & 109.23 & 343.03 & 127.55 \\
Aug. & 662.97 & 86.91 & 294.70 & 113.83 \\
Sep. & 501.22 & 70.70 & 223.48 & 96.06 \\
Oct. & 330.40 & 0.06 & 71.47 & 69.91 \\
Nov. & 120.10 & 0.00 & 6.87 & 16.96 \\
Dec. & 34.79 & 0.00 & 3.21 & 6.64 \\
\hline
\end{tabular}


Furthermore, the spatial distribution of IMD-derived gridded annual mean rainfall over KRB during 1901-2016 is shown in Figure 2b, from which it may be clearly observed that there is a decline in precipitation from the northeast to the southwest of the basin. The rainfall in the KRB varies from 1110.37 to $1763.49 \mathrm{~mm} /$ year. The annual mean rainfall in the basin progressively increases from the western to the eastern part of the basin, especially in the northeastern part of the basin. As per the figure, the maximum precipitation occurred in the northeastern parts of the basin (1763.49 mm/year), whereas the minimum (1110.37 mm/year) was in the western and southwestern parts of the basin.

\subsection{Monthly Analysis}

The non-parametric MK test together with Sen's slope was applied individually to each month of the 116 years precipitation time series. The results of the monthly precipitation trend in terms of $z$ statistics and slope were depicted in Table 3 . The results show considerable fluctuation, but there were no significant trends throughout the months, which is consistent with the previous findings [40-42]. The declined rainfall trend at rates of $-0.005 \mathrm{~mm}$ /year and $-0.003 \mathrm{~mm}$ /year was observed for the months of February and March, respectively, and at much greater rates for the monsoonal months (June-September) except for July $(-0.380,-0.514$, and $-0.337 \mathrm{~mm} /$ year, respectively). However, the July month of the monsoon season shows a very low increasing trend $(0.043 \mathrm{~mm} /$ year $)$, but the amount of rainfall received may not be enough to fulfill the required water demand. The rest of the months were also showing an increasing trend with a quite low magnitude varying from 0.00 to $0.058 \mathrm{~mm}$ /year. Among the monthly trend, the maximum negative magnitude was observed in August $(-0.514 \mathrm{~mm} /$ year $)$, while the positive magnitudes were seen for the month of May $(0.058 \mathrm{~mm} /$ year $)$.

Table 3. MK-test statistic and Sen's slope values for 116 years monthly precipitation.

\begin{tabular}{ccc}
\hline Time Scale & Z Statistic & Q (mm/year) \\
\hline Jan. & 0.81 & 0.006 \\
Feb. & -0.48 & -0.005 \\
Mar. & -0.27 & -0.003 \\
Apr. & 0.90 & 0.042 \\
May & 0.49 & 0.058 \\
Jun. & -1.73 & -0.380 \\
Jul. & 0.12 & 0.043 \\
Aug. & -1.55 & -0.514 \\
Sep. & -1.15 & -0.337 \\
Oct. & 0.20 & 0.021 \\
Nov. & 0.89 & 0.000 \\
Dec. & 1.67 & 0.000 \\
Annual & -2.53 & -1.880 \\
Monsoon & -2.43 & -0.408 \\
\hline
\end{tabular}

$\mathrm{Q}=$ magnitude of the trend, $\mathrm{Z}$ value = direction, bold value shows significant trend.

\subsection{Seasonal and Annual Precipitation Time-Series Trend Analysis}

In addition to the month-wise trend analysis, the seasonal (monsoon) and annual trend analysis of the 116 years of precipitation was carried out using the Mann-Kendall trend and the Sen's slope estimator for the magnitude of the trend. The results of the trend analysis of annual and seasonal precipitation are shown in Table 3. The analysis results revealed a decreasing trend in both annual and seasonal precipitation. The monsoon season is showing a negative change with $\mathrm{z}$ statistic value of -2.43 and Sen's slope of $-0.408 \mathrm{~mm} /$ year. For the annual trend, the $\mathrm{z}$ statistic and Sen's slope are -2.53 and $-1.880 \mathrm{~mm} /$ year, respectively. It can also be clearly observed from Figure 3 that there is a decreasing trend in both the annual and seasonal precipitation for the 1901 to 2016 time series. This significant declining trend in monsoon, as well as annual rainfall, may influence the agricultural practices, water resources of the basin, and ultimately, the economy of the 
nation. A similar significant decreasing trend of rainfall at annual and monsoon scales was also reported by Warwade et al. [41] over Bihar state, although the time period and data source were different. The decreasing trend in the monsoon season could be the main reason for the annual negative trend in the basin, as monsoon rainfall is the major source that accounted for $80 \%$ of the total precipitation received across the basin. The Land Use Land Cover (LULC) is the important driving factor that could be attributed to change in the rainfall pattern. Marengo [43] and Das, et al. [44] reported in their findings that increased urbanization and deforestation would significantly alter the water cycle and hydrology of that region and ultimately would lead to a change in climatic conditions. Some of the fascinating research studies reflected the rapid increasing trend of urban/build-up in the past few decades across the KRB [45-47]. These similar changing patterns of the LULC have also been reported in neighboring river basins [48-50]. These changing LULC trends may have had either a direct or indirect impact on the changing rainfall pattern in the region.
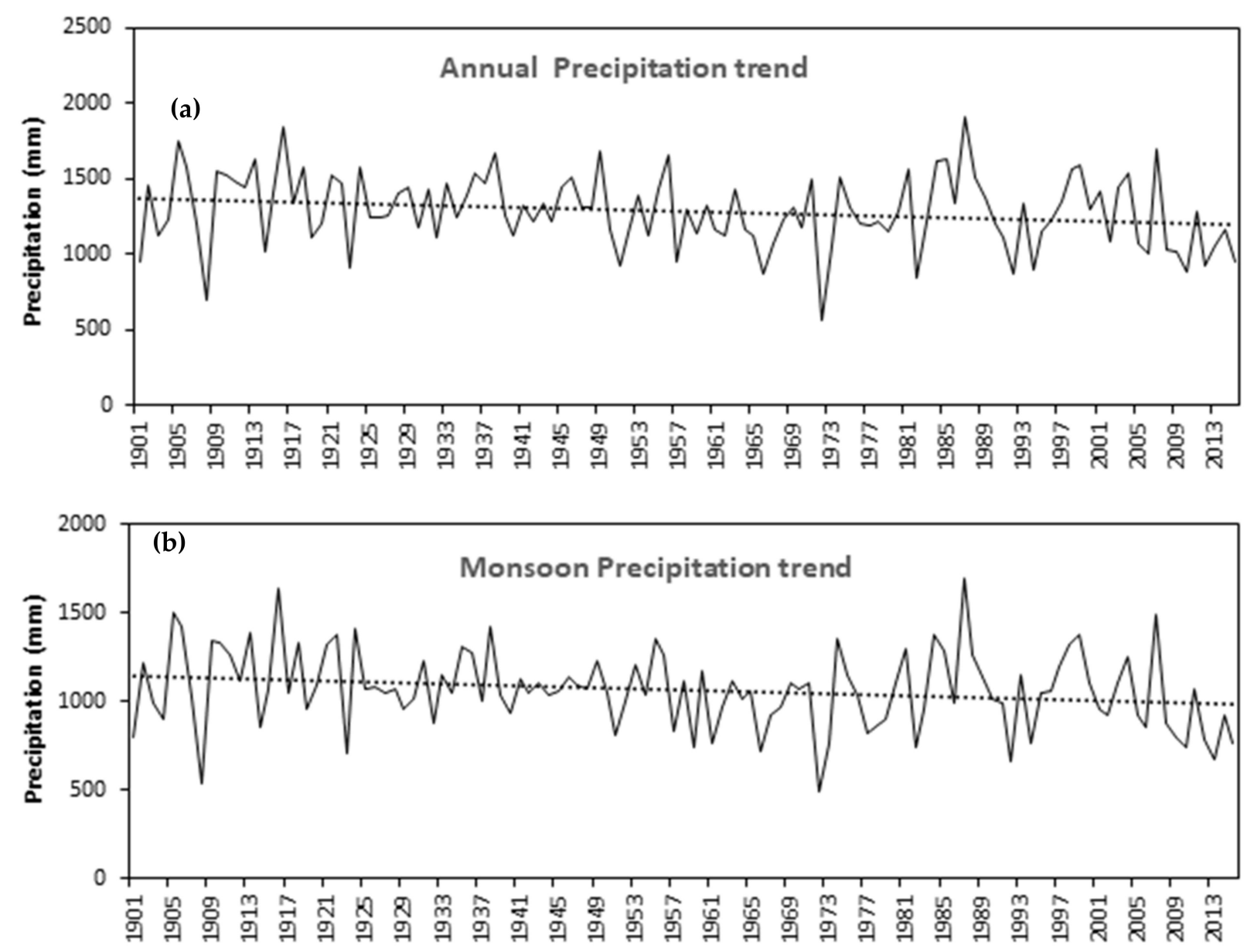

Figure 3. Temporal distribution of (a) annual precipitation and (b) monsoon seasonal precipitation of KRB.

\subsection{Spatial Variability in Long-Term Trend of Precipitation Time Series}

The spatial distribution of z-values as shown in Figure 4 revealed that the highest increasing trend was witnessed in the southeast of the study area, whereas the highest decreasing trend was in the western and central grids of the study area. It can also be clearly observed that there is a declining trend from the eastern to the western part of the study area. Most of the pixels in the eastern part of the river basin are showing an increasing trend, whereas the pixels lying in the southwards and western part of the basin reveal a decreasing trend. The spatial distribution of Sen's slope (magnitude of change) over the basin is shown in Figure 4. As per the figure, Sen's slope values vary from 8.85 
to $-4.56 \mathrm{~mm} /$ year. The highest magnitude of positive change is observed in the eastern and northeastern parts of the basin, whereas the maximum negative change is observed in the central part of the basin. Overall, in the last 116 years of precipitation, the eastern and northeastern parts of the basin were dominating with maximum positive precipitation change, and the western and central parts of the basin were showing moderately negative change. Moreover, a complicated variation in rainfall trend pattern was observed, which may impact and/or be impacted by the climate change in the basin [51-53]. Improved understanding of the spatio-temporal distribution and variability in rainfall trends has paramount importance for the planning and management of water resources in the basin.
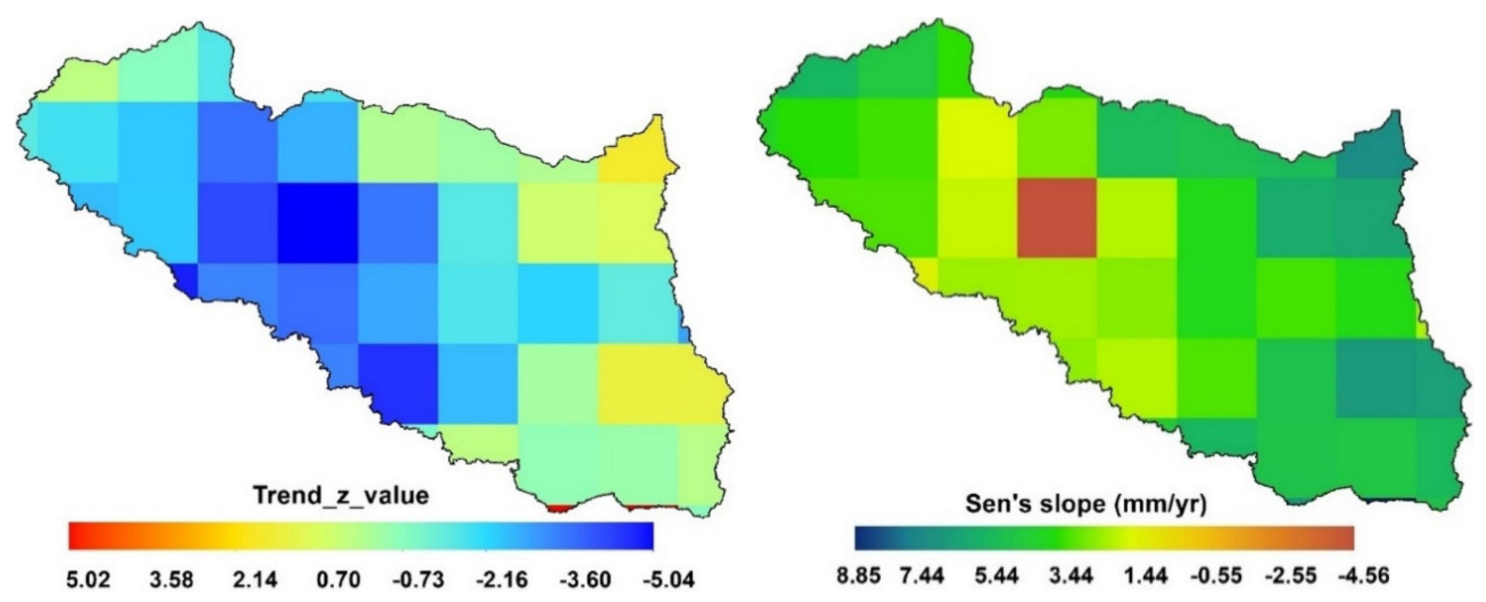

Figure 4. Spatial distribution of Sen's slope and MK test Z statistics over the KRB.

\subsection{Spatial Distribution of Extreme Precipitation Indices}

We analyzed the spatial distribution of five extreme precipitation indices at the KRB using the long-term (116 years) gridded precipitation datasets. CDD measures the length of consecutive dry days. As per Figure 5, the spatial distribution of CDD varies from 163 to 283 days. The length of the dry day is highest in the central and southern part of the basin (263 days), whereas the lowest number of days are found in the northeast part of the basin. The spatial distribution of precipitation in the basin is the main reason for the type of CDD distribution over the KRB. These findings are partially supported by the previous studies by Shrestha et al. [20], in which they showed the increasing trend of the station, which lies toward the southern part of the basin. Consecutive wet days measure the length of wet days where precipitation is greater than $1 \mathrm{~mm}$. The temporal trend of the 116 years datasets reveals an increasing trend of CWD over the KRB with a slope estimate of 0.048 days. In terms of the spatial distribution of the CWD, the maximum length is observed in the northeast and eastern part of the basin, and the lowest numbers are observed in the central and western parts of the basin. The RX1 day represents the most intense one-day precipitation over the region. The trend of RX1-day precipitation over the KRB during the 116 years of data reveals a decreasing trend with a slope of $-0.071 \mathrm{~mm}$. These findings are consistent with the studies of Manton, et al. [54], which indicate a decreasing trend of monthly maximum 1-day precipitation over Southeast Asia. Furthermore, Figure 5 shows the spatial distribution of the RX1-day precipitation over the KRB, which indicates that the northeast and eastern parts of the basin have the most intense precipitation from long-term data and the central and western part of the basin witnessed the lowest RX1-day precipitation. SDII indicates the simple daily intensity index precipitation over the KRB. The result shows that the intensity of daily precipitation is higher in the northeast and some other pixels lying on the upper region of the basin. As per Figure 5, there is a clear declining trend of SDII values from the northern to the southern part of the basin. Overall, the northern and particularly the northeastern part of the basin 
receives the highest volume and intensity precipitation compared to the southern and western parts of the basin.

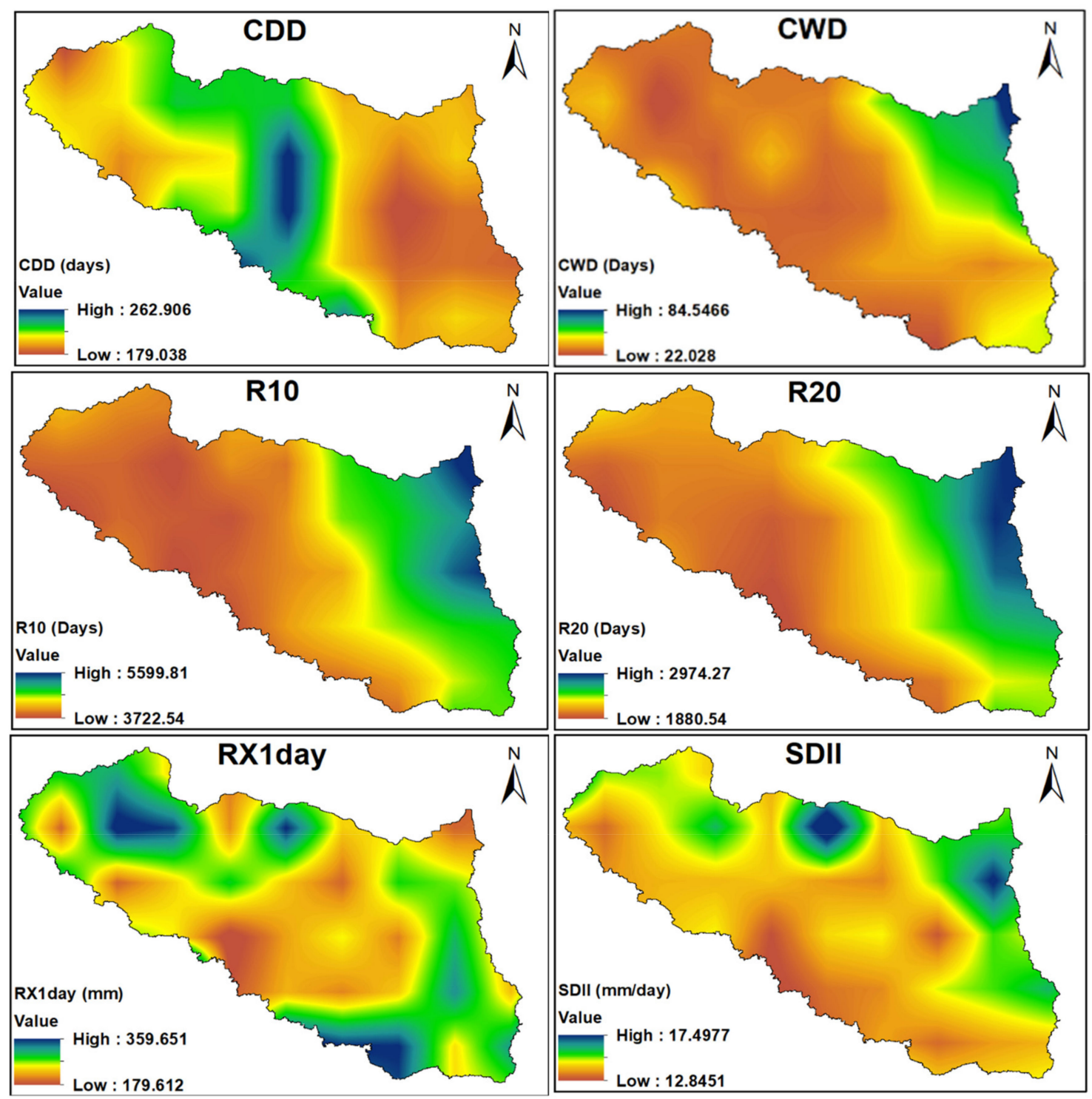

Figure 5. Spatial variability of extreme precipitation indices over the RRB during 1901-2016.

\subsection{Long-Term Trend in Extreme Precipitation Indices}

The regional average of extreme precipitation indices trends and their magnitude were analyzed at the basin scale, and the results are depicted in Figure 6. To assess the trend at the basin scale, grid values from the whole basin were arithmetically averaged. The trend was analyzed using the MK test, and the statistical significance of the trend was assessed at a $95 \%$ confidence interval $(p<0.05)$. We found a relatively decreasing trend in most of the extreme precipitation indices except for consecutive dry days (CDD) and consecutive wet days (CWD). The result revealed that the lengths of the CDD and CWD show an increasing (positive) trend with Sen's slope values of 0.066 and 0.048 days, respectively. However, the RX1 day, R10, and SDII show a decreasing trend with Sen's slope values of $-0.071 \mathrm{~mm}$, -0.043 day, and $-0.011 \mathrm{~mm} /$ day, respectively. The $p$-values were considered for the analysis of significance of the trend. Results reveal that except for the SDII index, all the remaining indices show a non-significant trend at 95\% confidence interval. A similar result was also reported by Singh, et al. [55], Shrestha et al., and Sivakumar and Stefanski [56], 
in which they indicate the increasing frequency of dryness and CCD trend. Moreover, Rajbhandari, et al. [57] estimated the projections of future changes in extreme rainfall events and found that the frequency of rainfall will decreases with an increase in CDD almost throughout the basin.
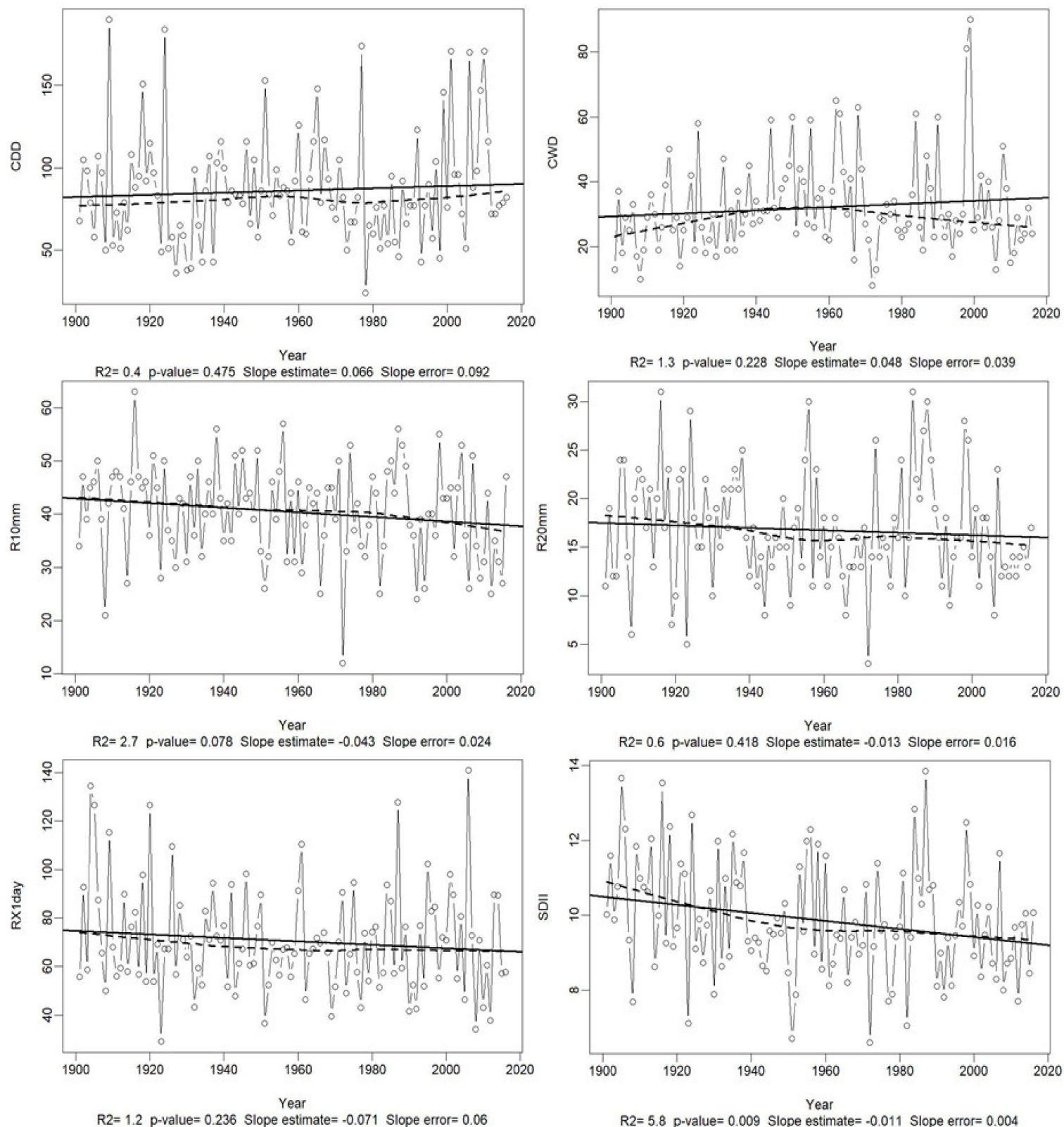

Figure 6. Regionally averaged anomaly of various precipitation extreme indices with line trend (straight line) and best fitting (dotted line) over KRB from 1901 to 2016.

\section{Conclusions}

This study analyzed the long-term trend (116 years) in precipitation and extreme precipitation indices in the KRB, which is one of the frequent flooding rivers of Bihar, India using the gridded IMD precipitation datasets. The precipitation characteristics of the KRB show spatial and temporal variability. The results highlighted that January, April, May, July, October, November, and December are depicting increasing trends. Conversely, the months of February, March, June, August, and September are depicting decreasing trends. Furthermore, the analysis reveals a significant decreasing trend in monsoonal 
and annual precipitation. The monsoon season trend was found to be representative of the annual rainfall trend. Overall, the rainfall trend shows a mixed pattern of changes in rainfall pattern, which supports the KRB becoming generally drier in the monsoon period. This gives a clear indication of a dry spell during the major crop-growing Kharif season that would impact crop productivity and lead to food insecurity. Sen's slope also depicts an increasing and decreasing magnitude of slope corresponding with the MK test z-values. The results of extreme precipitation also showed that at the basin scale, the RX1 day, R20 mm, and SDII were decreasing. The information regarding the longterm rainfall and extreme precipitation trends could have greater significance in water management, irrigation scheduling, and may play an important role in flood management, runoff, and related hydrological process of the basin. The Indo-Gangetic plains part of the KRB is densely populated; where the majority of people live below the poverty line with vulnerable and low coping capacity. Thus, there is a need for a robust understanding of the vulnerability of the basin in terms of hydrological extreme characteristics for adopting good practices. This study will help the relevant environmental managers to framework potential socio-economic systems, especially water resources and agricultural productivity to safeguard food and water security. Finally, the cause of the changes requires further investigation to establish the relation between climate variability and the observed trends over the KRB.

Author Contributions: Conceptualization, P.K.S.; Data curation, A.K.S.; Formal analysis, R.K.P., M.G., A.Y., V.P., and A.K.S.; Funding acquisition, P.K.S., G.P.P., and R.K.M.; Investigation, W.Z.W.J. and R.K.M.; Methodology, P.K.S.; Project administration, P.K.S.; Resources, P.K.S.; Supervision, P.K.S.; Writing—original draft, P.K.S. and R.K.P.; Writing—review and editing, P.K.S., G.P.P., M.G., V.P., and W.Z.W.J. All authors have read and agreed to the published version of the manuscript.

Funding: “This research was funded by SERB, Department of Science \& Technology (DST), grant number ECR/2015/000448".

Institutional Review Board Statement: Not applicable.

Informed Consent Statement: Not applicable.

Data Availability Statement: Data may be available after request to Indian Meteorological Department, Government of India.

Acknowledgments: I would like to sincerely thank the SERB, Department of Science \& Technology (DST) for providing the research grant for the research work (DST No: ECR/2015/000448). The author also thanks the Indian Meteorological Department and National Data Centre, Pune for providing the datasets for the research. We are also thankful to Xuebin Zhang and Feng Yang from the Canadian Meteorological Service to provide the RClimdex tool. Finally, I would like to acknowledge Banaras Hindu University for providing the platform and support for the research work.

Conflicts of Interest: The authors declare no conflict of interest.

\section{References}

1. Xia, X.; Wu, Q.; Mou, X.; Lai, Y. Potential impacts of climate change on the water quality of different water bodies. J. Environ. Informatics 2015, 25, 85-98. [CrossRef]

2. Basher, M.A.; Stiller-Reeve, M.A.; Islam, A.S.; Bremer, S. Assessing climatic trends of extreme rainfall indices over northeast Bangladesh. Theor. Appl. Climatol. 2018, 134, 441-452. [CrossRef]

3. Moss, R.H.; Meehl, G.A.; Lemos, M.C.; Smith, J.B.; Arnold, J.; Arnott, J.C.; Behar, D.; Brasseur, G.P.; Broomell, S.; Busalacchi, A. Hell and high water: Practice-relevant adaptation science. Science 2013, 342, 696-698. [CrossRef]

4. Mall, R.K.; Gupta, A.; Singh, R.; Singh, R.S.; Rathore, L. Water resources and climate change: An Indian perspective. Curr. Sci. 2006, 1610-1626.

5. Sridhar, S.; Raviraj, A. Statistical Trend Analysis of Rainfall in Amaravathi River Basin using Mann-Kendall Test. Curr. World Environ. 2017, 12. [CrossRef]

6. Bera, S. Trend analysis of rainfall in Ganga Basin, India during 1901-2000. Am. J. Clim. Chang. 2017, 6, 116. [CrossRef]

7. Gajbhiye, S.; Meshram, C.; Singh, S.K.; Srivastava, P.K.; Islam, T. Precipitation trend analysis of Sindh River basin, India, from 102-year record (1901-2002). Atmos. Sci. Lett. 2016, 17, 71-77. [CrossRef] 
8. Mishra, N.; Kumar, M.; Kumar, S. Trend Analysis of Precipitation by MK Test in Kumaon Region of Uttarakhand (1901-2010). Indian J. Sci. Technol. 2016, 9. [CrossRef]

9. Pandit, D.V. Seasonal Rainfall Trend Analysis. Int. J. Eng. Res. Appl. 2016, 6, 69-73.

10. Chaubey, P.K.; Srivastava, P.K.; Gupta, A.; Mall, R.K. Integrated assessment of extreme events and hydrological responses of Indo-Nepal Gandak River Basin. Environ. Dev. Sustain. 2021, 23, 8643-8668. [CrossRef]

11. Hadi, S.J.; Tombul, M. Long-term spatiotemporal trend analysis of precipitation and temperature over Turkey. Meteorol. Appl. 2018, 25, 445-455. [CrossRef]

12. Rustum, R.; Adeloye, A.J.; Mwale, F. Spatial and temporal Trend Analysis of Long Term rainfall records in data-poor catchments with missing data, a case study of Lower Shire floodplain in Malawi for the Period 1953-2010. Hydrol. Earth Syst. Sci. Discuss 2017. preprint. [CrossRef]

13. Howard, G.; Calow, R.; Macdonald, A.; Bartram, J. Climate change and water and sanitation: Likely impacts and emerging trends for action. Annu. Rev. Environ. Resour. 2016, 41, 253-276. [CrossRef]

14. Mall, R.K.; Srivastava, R.K.; Banerjee, T.; Mishra, O.P.; Bhatt, D.; Sonkar, G. Disaster Risk Reduction Including Climate Change Adaptation Over South Asia: Challenges and Ways Forward. Int. J. Disaster Risk Sci. 2019, 10, 14-27. [CrossRef]

15. Kumar, V.; Jain, S.K.; Singh, Y. Analysis of long-term rainfall trends in India. Hydrol. Sci. J. J. Sci. Hydrol. 2010, 55, 484-496. [CrossRef]

16. Panda, R.K.; Singh, G. Analysis of Trend and Variability of Rainfall in the Mid-Mahanadi River Basin of Eastern India. Analysis 2016, 1608, 53049 .

17. Mirza, M.; Warrick, R.; Ericksen, N.; Kenny, G. Trends and persistence in precipitation in the Ganges, Brahmaputra and Meghna river basins. Hydrol. Sci. J. 1998, 43, 845-858. [CrossRef]

18. Chandrakar, A.; Khare, D.; Krishan, R. Assessment of Spatial and Temporal Trends of Long Term Precipitation over Kharun Watershed, Chhattisgarh, India. Environ. Process. 2017, 4, 959-974. [CrossRef]

19. Kumar Pradhan, R.; Srivastava, P.K.; Maurya, S.; Kumar Singh, S.; Patel, D.P. Integrated framework for soil and water conservation in Kosi River Basin. Geocarto Int. 2020, 35, 391-410. [CrossRef]

20. Shrestha, A.B.; Bajracharya, S.R.; Sharma, A.R.; Duo, C.; Kulkarni, A. Observed trends and changes in daily temperature and precipitation extremes over the Koshi river basin 1975-2010. Int. J. Climatol. 2017, 37, 1066-1083. [CrossRef]

21. Nepal, S. Impacts of climate change on the hydrological regime of the Koshi river basin in the Himalayan region. J. Hydro Environ. Res. 2016, 10, 76-89. [CrossRef]

22. Agarwal, A.; Babel, M.S.; Maskey, S. Analysis of future precipitation in the Koshi river basin, Nepal. J. Hydrol. 2014, 513, 422-434 [CrossRef]

23. Gupta, K.S.N. Towards enhanced disaster risk reduction in the Koshi River basin: A look at the downstream reaches of Bihar in India. Available online: https:/ / www.icimod.org/article/towards-enhanced-disaster-risk-reduction-in-the-koshi-river-basina-look-at-the-downstream-reaches-of-bihar-in-india/ (accessed on 16 July 2020).

24. Sahana, M.; Patel, P.P. A comparison of frequency ratio and fuzzy logic models for flood susceptibility assessment of the lower Kosi River Basin in India. Environ. Earth Sci. 2019, 78, 1-27. [CrossRef]

25. Sinha, R.; Bapalu, G.; Singh, L.; Rath, B. Flood risk analysis in the Kosi river basin, north Bihar using multi-parametric approach of analytical hierarchy process (AHP). J. Indian Soc. Remote. Sens. 2008, 36, 335-349. [CrossRef]

26. Pai, D.; Sridhar, L.; Rajeevan, M.; Sreejith, O.; Satbhai, N.; Mukhopadhyay, B. Development of a new high spatial resolution $(0.25 \times 0.25)$ long period (1901-2010) daily gridded rainfall data set over India and its comparison with existing data sets over the region. Mausam 2014, 65, 1-18.

27. Prakash, S. Performance assessment of CHIRPS, MSWEP, SM2RAIN-CCI, and TMPA precipitation products across India. J. Hydrol. 2019, 571, 50-59. [CrossRef]

28. Bae, D.H.; Jung, I.W.; Chang, H. Long-Term trend of precipitation and runoff in Korean river basins. Hydrol. Process. 2008, 22, 2644-2656. [CrossRef]

29. Asfaw, A.; Simane, B.; Hassen, A.; Bantider, A. Variability and time series trend analysis of rainfall and temperature in northcentral Ethiopia: A case study in Woleka sub-basin. Weather. Clim. Extrem. 2018, 19, 29-41. [CrossRef]

30. Longobardi, A.; Villani, P. Trend analysis of annual and seasonal rainfall time series in the Mediterranean area. Int. J. Climatol. 2010, 30, 1538-1546. [CrossRef]

31. Ahmad, I.; Tang, D.; Wang, T.; Wang, M.; Wagan, B. Precipitation Trends over Time Using Mann-Kendall and Spearman's rho Tests in Swat River Basin, Pakistan. Adv. Meteorol. 2015, 2015, 1-15. [CrossRef]

32. Salami, A.; Ikpee, O.; Ibitoye, A.; Oritola, S. Trend analysis of hydro-meteorological variables in the coastal area of Lagos using Mann-Kendall trend and Standard Anomaly Index methods. J. Appl. Sci. Environ. Manag. 2016, 20, 797-808. [CrossRef]

33. Okafor, G.C.; Jimoh, O.; Larbi, K.I. Detecting Changes in Hydro-Climatic Variables during the Last Four Decades (1975-2014) on Downstream Kaduna River Catchment, Nigeria. Atmos. Clim. Sci. 2017, 7, 161. [CrossRef]

34. Sen, P.K. Estimates of the regression coefficient based on Kendall's tau. J. Am. Stat. Assoc. 1968, 63, 1379-1389. [CrossRef]

35. Drápela, K.; Drápelová, I. Application of Mann-Kendall test and the Sen's slope estimates for trend detection in deposition data from Bílý Kř́ž (Beskydy Mts., the Czech Republic) 1997-2010. Beskydy 2011, 4, 133-146.

36. Sharma, A.; Sharma, D.; Panda, S.; Dubey, S.K.; Pradhan, R.K. Investigation of temperature and its indices under climate change scenarios over different regions of Rajasthan state in India. Glob. Planet. Chang. 2018, 161, 82-96. [CrossRef] 
37. Pradhan, R.K.; Sharma, D.; Panda, S.; Dubey, S.K.; Sharma, A. Changes of precipitation regime and its indices over Rajasthan state of India: Impact of climate change scenarios experiments. Clim. Dyn. 2019, 52, 3405-3420. [CrossRef]

38. Sillmann, J.; Kharin, V.; Zhang, X.; Zwiers, F.; Bronaugh, D. Climate extremes indices in the CMIP5 multimodel ensemble: Part 1. Model evaluation in the present climate. J. Geophys. Res. Atmos. 2013, 118, 1716-1733. [CrossRef]

39. Kim, Y.; Rocheta, E.; Evans, J.P.; Sharma, A. Impact of bias correction of regional climate model boundary conditions on the simulation of precipitation extremes. Clim. Dyn. 2020, 55, 3507-3526. [CrossRef]

40. Tank, A.M.G.K.; Peterson, T.C.; Quadir, D.A.; Dorji, S.; Zou, X.; Tang, H.; Santhosh, K.; Joshi, U.R.; Jaswal, A.K.; Kolli, R.K.; et al. Changes in daily temperature and precipitation extremes in central and south Asia. J. Geophys. Res. Space Phys. 2006, $111,111$. [CrossRef]

41. Warwade, P.; Tiwari, S.; Ranjan, S.; Chandniha, S.K.; Adamowski, J. Spatio-temporal variation of rainfall over Bihar State, India. J. Water Land Dev. 2018, 36, 183-197. [CrossRef]

42. Zakwan, M.; Ara, Z. Statistical analysis of rainfall in Bihar. Sustain. Water Resour. Manag. 2019, 5, 1781-1789. [CrossRef]

43. Marengo, J.A. On the hydrological cycle of the Amazon Basin: A historical review and current state-of-the-art. Rev. Bras. Meteorol. 2006, 21, 1-19.

44. Das, P.; Behera, M.D.; Patidar, N.; Sahoo, B.; Tripathi, P.; Behera, P.R.; Srivastava, S.; Roy, P.S.; Thakur, P.; Agrawal, S. Impact of LULC change on the runoff, base flow and evapotranspiration dynamics in eastern Indian river basins during 1985-2005 using variable infiltration capacity approach. J. Earth Syst. Sci. 2018, 127, 1-19. [CrossRef]

45. Rai, P.K.; Chandel, R.S.; Mishra, V.N.; Singh, P. Hydrological inferences through morphometric analysis of lower Kosi river basin of India for water resource management based on remote sensing data. Appl. Water Sci. 2018, 8, 1-16. [CrossRef]

46. Rimal, B.; Sharma, R.; Kunwar, R.; Keshtkar, H.; Stork, N.E.; Rijal, S.; Rahman, S.A.; Baral, H. Effects of land use and land cover change on ecosystem services in the Koshi River Basin, Eastern Nepal. Ecosyst. Serv. 2019, 38, 100963. [CrossRef]

47. Paudel, B.; Gao, J.; Zhang, Y.; Wu, X.; Li, S.; Yan, J. Changes in cropland status and their driving factors in the Koshi River basin of the Central Himalayas, Nepal. Sustainability 2016, 8, 933. [CrossRef]

48. Das, P.; Behera, M.; Pal, S.; Chowdary, V.; Behera, P.; Singh, T. Studying land use dynamics using decadal satellite images and Dyna-CLUE model in the Mahanadi River basin, India. Environ. Monit. Assess. 2019, 191, 1-17. [CrossRef] [PubMed]

49. Shukla, A.K.; Ojha, C.S.P.; Mijic, A.; Buytaert, W.; Pathak, S.; Garg, R.D.; Shukla, S. Population growth, land use and land cover transformations, and water quality nexus in the Upper Ganga River basin. Hydrol. Earth Syst. Sci. 2018, 22, 4745-4770. [CrossRef]

50. Mitra, S.; Roy, A.K.; Tamang, L. Assessing the status of changing channel regimes of Balason and Mahananda River in the Sub-Himalayan West Bengal, India. Earth Syst. Environ. 2020, 4, 409-425. [CrossRef]

51. Alahacoon, N.; Edirisinghe, M. Spatial Variability of Rainfall Trends in Sri Lanka from 1989 to 2019 as an Indication of Climate Change. ISPRS Int. J. Geo Inf. 2021, 10, 84. [CrossRef]

52. Shah, N.; Patel, Y.; DBhangaonkar, P. Assessing Impact of Climate Change on Rainfall Patterns of Vadodara District, Gujarat, India. In In Proceedings of the Journal of Physics, Conference Series, Goa, India, 24-25 October 2020; p. 012046.

53. Onyutha, C.; Tabari, H.; Rutkowska, A.; Nyeko-Ogiramoi, P.; Willems, P. Comparison of different statistical downscaling methods for climate change rainfall projections over the Lake Victoria basin considering CMIP3 and CMIP5. J. Hydro Environ. Res. 2016, 12, 31-45. [CrossRef]

54. Manton, M.J.; Della-Marta, P.M.; Haylock, M.R.; Hennessy, K.; Nicholls, N.; Chambers, L.; Collins, D.; Daw, G.; Finet, A.; Gunawan, D. Trends in extreme daily rainfall and temperature in Southeast Asia and the South Pacific: 1961-1998. Int. J. Climatol. 2001, 21, 269-284. [CrossRef]

55. Singh, D.; Tsiang, M.; Rajaratnam, B.; Diffenbaugh, N.S. Observed changes in extreme wet and dry spells during the South Asian summer monsoon season. Nat. Clim. Chang. 2014, 4, 456-461. [CrossRef]

56. Sivakumar, M.V.; Stefanski, R. Climate change in South Asia. In Climate change and food security in South Asia; Springer: New York, NY, USA, 2010; pp. 13-30.

57. Rajbhandari, R.; Shrestha, A.B.; Nepal, S.; Wahid, S.; Ren, G.-Y. Extreme climate projections over the transboundary Koshi River Basin using a high resolution regional climate model. Adv. Clim. Chang. Res. 2017, 8, 199-211. [CrossRef] 